\title{
Effects of water and potassium stresses on potassium utilization efficiency of two cotton genotypes
}

\author{
X. Wang ${ }^{1,2}$, I. Mohamed ${ }^{1,4}$, Y.Xia ${ }^{1,2}$, F. Chen ${ }^{1,3 *}$ \\ ${ }^{1}$ Key Laboratory of Aquatic Botany and Watershed Ecology, Chinese Academy of Science, Wuhan, 430074, \\ China. \\ *Corresponding author: fchen@ipni.ac.cn \\ ${ }^{2}$ Graduate University, Chinese Academy of Sciences, Beijing, 100049, China. \\ ${ }^{3}$ China Program of International Plant Nutrition Institute, Wuhan, 430074, China. \\ ${ }^{4}$ Soil Science Department, Faculty of Agriculture, Benha University, Moshtohor, Toukh, Kalyoubia, 13736, Egypt.
}

\begin{abstract}
Potassium utilization efficiency (KUE) for plants is related to genotype difference, soil characteristics, application of fertilizer and irrigation. Up to now, the KUE of different genotypes worldwide has been extensively studied, but the influence of environment stress on KUE of cotton is infrequently reported. Thus, we selected a high $\mathrm{K}$ utilization efficiency cotton genotype (HEG) and a low K utilization efficiency cotton genotype (LEG) as indicator plants. The results showed that both soil water stress and $\mathrm{K}$ stress limited the growth of cotton genotypes. The change of soil water levels had significant influence on yield, KUE, rates of fallen leaves and bolls (RF), biomass and potassium accumulation in cotton. Deficient of soil water restricted the uptake and translocation of $\mathrm{K}$. The absence of soil $\mathrm{K}$ greatly increased the proportion of biomass of reproductive organs and $\mathrm{K}$ distribution to reproductive organs in this experiment. The HEG exhibited higher physiological compared with LEG under the stress conditions, especially under low K treatment.
\end{abstract}

Keywords: Cotton genotypes, K uptake, K utilization efficiency. 


\section{Introduction}

Soil moisture, fertilizer and temperature are important factors affecting plant growth and agricultural production (Quezada et al. 2011; Hattori et al. 2013). Soil moisture can play a vital role in the mineralization process of fertilizers and organic amendments, which release nutrients in soil for use by plants. The decrease of soil moisture has negative effects on the interception, mass flow and diffusion of nutrients and then decreasing growth of plants (Mu 1999).

$\mathrm{K}$ is one of the essential nutrients and the presence of an adequate amount of $\mathrm{K}$ in the soil can enhance growth, yield and quality of cotton (Mullins et al. 1997; Adeli and Varco 2002; Gormus 2002; Reddy and Zhao 2005; Pettigrew 2008) by improving the effectiveness of photosynthesis process, resistance to diseases, and water utilization efficiency (Jiang et al. 2011). Some studies indicated that plant $\mathrm{K}$ availability was related to soil water content, which highly influenced the mass flow and diffusion rates of $\mathrm{K}$ in soils (Moritsuka et al. 2000; Doussan et al. 2003).

Cotton belongs to the tribe Gossypieae in mallow family (Malvaceae), and is an important natural source for fibers. Cotton has a huge requirement for $\mathrm{K}$, and very sensitive to soil $\mathrm{K}$ deficiency (Adeli and Varco 2002). With average crop productivity, cotton can remove about 150 $\mathrm{kg} \mathrm{K} \mathrm{K}_{2} \mathrm{O} / \mathrm{ha}$ from soil (Saparov et al. 2013). Meanwhile, cotton is a drought-resistant plant, but the absence of soil moisture can restrict its nutrient uptake capability and the transportation of nutrients. Cotton genotypes with different $\mathrm{K}$ utilization efficiency (KUE) should have various physiological reactions and biological indicators (Yang et al. 2010) under water and $\mathrm{K}$ deficit conditions. Xia et al. (2011) found significant differences $(P<0.05)$ in morphological and physiological characteristics of two cotton genotypes under stress conditions. Moreover, they observed that at the reproductive stage, plant heights and leaf numbers of HEG (a high $\mathrm{K}$ utilization efficiency cotton genotype) were lower than those of LEG (a low K utilization efficiency cotton genotype), but the number of squares and bolls were higher in HEG than in LEG with the increase of $\mathrm{K}$ fertilizer rates. Tao et al. (2012) found that vessel frequencies of root, stem and petiole, and nutrients uptake of HEG were significantly higher than those of LEG at boll development stage.

The effects of K levels on yield, quality, dry matter weight, root-shoot ratio, reproductive growth to vegetative growth ratio and harvest index of cotton genotypes have been extensively explored (Makhdum et al. 2007; Clement-Bailey and Gwathmey 2007; Gwathmey et al. 2009; Xia et al. 2011; Jiang et al. 2011). Nevertheless, K utilization efficiency (KUE) among cotton cultivars or genotypes in response to different $\mathrm{K}$ and soil moisture levels have not documented well.

\section{Materials and Methods}

In order to explore the objective as outlined above, a pot experiment was conducted at 
Wuhan Botanical Garden, Chinese Academy of Sciences, Wuhan city, Hubei province, China $\left(30^{\circ} 32.716^{\prime} \mathrm{N}, 114^{\circ} 24.996^{\prime} \mathrm{E}\right)$.

\subsection{Experiment description of growth conditions}

The pot experiment was carried out from May to October in 2011 in a wire house with rainproof roof, in order to avoid interruption by rainfall. The indoor environment of the wire house was kept similar to the outdoor environment. Monthly temperatures during the cotton growing season were $27.9^{\circ} \mathrm{C}\left(18-35^{\circ} \mathrm{C}\right)$ in May, $29.5^{\circ} \mathrm{C}$ $\left(23-33^{\circ} \mathrm{C}\right)$ in June, $33^{\circ} \mathrm{C}\left(29-36^{\circ} \mathrm{C}\right)$ in July, $31.4^{\circ} \mathrm{C}\left(25-36^{\circ} \mathrm{C}\right)$ in August, $26.3^{\circ} \mathrm{C}\left(19-33^{\circ} \mathrm{C}\right)$ in September, and $20.1^{\circ} \mathrm{C}\left(14-30^{\circ} \mathrm{C}\right)$ in October, respectively.

The soil was collected from the surface layer (0-15 cm) of a yellow-brown soil from Wuhan Botanical Garden, Chinese Academy of Sciences. It was characterized with a $\mathrm{pH}$ of 6.1 (water : soil $=2.5: 1.0$ ), organic matters of $24.7 \mathrm{~g}$ $\mathrm{kg}^{-1}$ (digested with potassium dichromate under strong acid), alkaline hydrolysis $\mathrm{N}$ of $87.3 \mathrm{mg}$ $\mathrm{kg}^{-1}$ (extracted with $1 \mathrm{~mol} \mathrm{~L}^{-1} \mathrm{NaOH}$ ), Olsen-P of $16.8 \mathrm{mg} \mathrm{kg}^{-1}$ (extracted with $0.03 \mathrm{~mol} \mathrm{~L}^{-1} \mathrm{NH}_{4} \mathrm{~F}$ and $0.025 \mathrm{~mol} \mathrm{~L}^{-1} \mathrm{HCl}$ ), rapidly available $\mathrm{K}$ of $82.5 \mathrm{mg} \mathrm{kg}^{-1}$ (extracted with $1 \mathrm{~mol} \mathrm{~L}^{-1} \mathrm{NH}_{4} \mathrm{OAC}$ ), which was defined as very low $\mathrm{K}$ level based on the new soil test interpretation classes for soil available K (Mallarino et al. 2003).

The two chosen cotton (Gossypium hirsutum L.) cultivars, high and low $\mathrm{K}$ utilization efficiencies
(HEG and LEG) were carefully screened from 86 cotton cultivars. HEG had high $\mathrm{K}$ utilization efficiency and yield, whereas LEG had the opposite. They were provided by the Crop Breeding Department at Huazhong Agricultural University with original ID numbers of 103 and 122.

\subsection{Experimental design and treatments}

The experiment was set up in a complete randomized design with five replicates for each treatment. The experimental pots were filled with $4 \mathrm{~kg}$ soil and then planted with five cotton seeds. After one week, cotton plants were thinned to one plant per pot. Four treatments were organized in this experiment: optimum water and $\mathrm{K}(\mathrm{OPT})$, water deficiency (OPT-W), $\mathrm{K}$ deficiency (OPT-K) and deficiency of water and $\mathrm{K}$ (OPT-W-K).

According to determination of the experimental soil and our previous experience, the optimal $\mathrm{K}$ rate for cotton was $160 \mathrm{~kg} \mathrm{ha}^{-1}$ based on local recommendations (Wang 2002; Xia et al. 2013). The plant pot has a surface of $0.02416 \mathrm{~m}^{2}(16 \mathrm{~cm}$ $\times 15.1 \mathrm{~cm})$, so about $3.86 \mathrm{~g} \mathrm{KCl}(49.8 \% \mathrm{~K})$ was supplied to each pot. Nitrogen fertilizer (urea) was applied 4 times during the cotton-growing season. Firstly, $1.04 \mathrm{~g}$ per pot urea was applied before sowing and then $0.70 \mathrm{~g}$ per plot were added at each of squaring, peak bloom stage and boll stages, respectively. Fertilizer $\mathrm{P}$ and $\mathrm{K}$ were applied before sowing. The amounts of fertilizers used were provided in Table 1. 
Table 1. Sources of fertilizers and their amounts $\left(\mathrm{g} \mathrm{kg}^{-1}\right)$ added to soil, and soil water contents for different treatments.

\begin{tabular}{|c|c|c|c|c|}
\hline \multirow{2}{*}{ Treatment } & \multicolumn{3}{|c|}{ Sources and amounts of fertilizers } & \multirow{2}{*}{$\begin{array}{c}\text { Soil } \\
\text { water } \\
\text { content }\end{array}$} \\
\hline & $\mathrm{CO}\left(\mathrm{NH}_{2}\right)_{2}$ & $\mathrm{Ca}\left(\mathrm{H}_{2} \mathrm{PO}_{4}\right)_{2} \cdot \mathrm{H}_{2} \mathrm{O}$ & $\mathrm{KCl}$ & \\
\hline $\begin{array}{l}\text { Optimum water and } \mathrm{K} \\
\text { (OPT) }\end{array}$ & 0.78 & 2.33 & 0.97 & $35 \%$ \\
\hline $\begin{array}{l}\text { Water deficiency } \\
\text { (OPT-W) }\end{array}$ & 0.78 & 2.33 & 0.97 & $25 \%$ \\
\hline $\begin{array}{l}\text { K deficiency } \\
\text { (OPT-K) }\end{array}$ & 0.78 & 2.33 & 0.00 & $35 \%$ \\
\hline $\begin{array}{l}\text { Deficiency of water and } \mathrm{K} \\
\text { (OPT-W-K) }\end{array}$ & 0.78 & 2.33 & 0.00 & $25 \%$ \\
\hline
\end{tabular}

Soil water content depended on results of our previous experiment (unpublished data). $25 \%$ and $35 \%$ of volumetric water content of soil were defined as low water stress condition and suitable water condition, respectively. The two chosen cottons could grow well in volumetric water content of $35 \%$ and had significant yield difference compared to that in volumetric water content of $25 \%$ (Wang et al. 2012). A portable soil moisture equipment-Theta Probe (WET, Delta-T, USA) based on time domain reflectometry was used to measure and monitor soil moisture every 3-4 days. During summer, when the temperature was higher, soil moisture was monitored every day.

\subsection{Plant analysis}

After the harvesting of cotton, plants were separated, weighted, and dried at $60{ }^{\circ} \mathrm{C}$ for 72 $h$, and then digested with a mixture of $\mathrm{H}_{2} \mathrm{SO}_{4}$ and $\mathrm{H}_{2} \mathrm{O}_{2}(2: 1)$. $\mathrm{K}$ content of plant samples was determined using flame photometer, while $\mathrm{K}$ utilization efficiency (KUE) was defined as the ratio of crop yield per unit plant $\mathrm{K}$ content. This parameter indicated the ability of a plant to use K for vegetative and reproductive growth (White, 2013). $\mathrm{KUE}=$ yield $/ \mathrm{K}$ amount in the plant.

\subsection{Statistical analysis}

All data were analyzed using Two-way ANOVA procedure in Microsoft-Excel and SPSS statistical software package (ver.16.0). Tukey's test was used to evaluate significant differences between treatments at $p<0.05$.

\section{Results}

\subsection{Yield and biomass}

As shown in Figure 1, dry matter weight (DMW) of seed cottons, bolls, roots and the total DMW of HEG under the studied treatments were higher than those of LEG, whereas the DMW of stems, leaves and the litters of HEG were lower than those of LEG. In this experiment, the DMW of different organs of HEG and LEG under water stress were lower than that under $\mathrm{K}$ stress. This indicated that water played a more 
important role in for biomass accumulation than K. Figure 1 also showed that the DMW of HEG cotton roots were higher than those of LEG, demonstrating that HEG had stronger uptake capacity and higher nutrient supplying ability than LEG. It can also be inferred from Figure 1 that HEG recorded higher uptake capacity and nutrient supplying ability than LEG due to the greater DMW of HEG roots as compared to those of LEG.
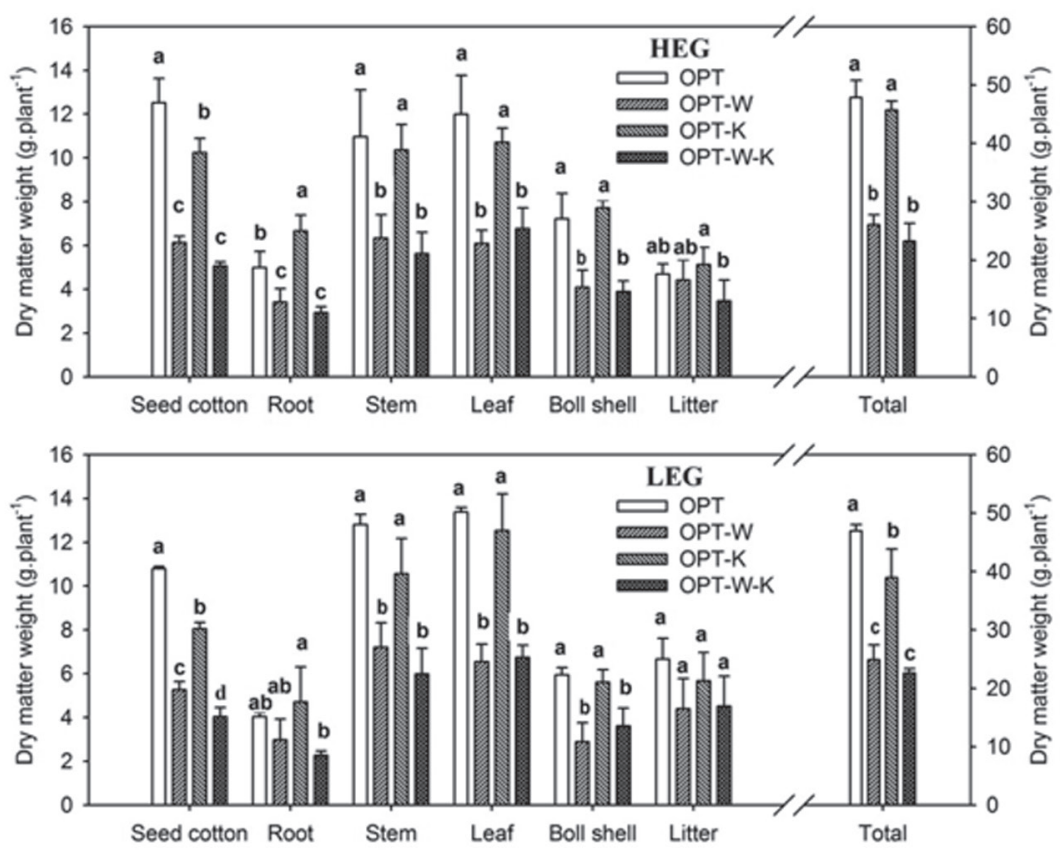

Figure 1. Effects of different water and $\mathrm{K}$ treatments on dry matter weights of two cotton genotypes. Bars represent means of 5 replications \pm standard errors $(n=4)$. Different letters indicated the significant differences between the treatments by Tukey's multiple range test $(P<0.05)$. OPT $=$ Optimum water and $\mathrm{K}, \mathrm{OPT}-\mathrm{W}=$ Water stress, $\mathrm{OPT}-\mathrm{K}=\mathrm{K}$ stress, $\mathrm{OPT}-\mathrm{W}-\mathrm{K}=$ water and $\mathrm{K}$ stresses.

\subsection{K concentration and accumulation}

Data in Table 2 presented that a higher application rate of $\mathrm{K}$ fertilizer was responsible for larger $\mathrm{K}$ concentrations in all organs. When $\mathrm{K}$ was sufficient, $\mathrm{K}$ concentrations were high in leaves and reproductive organs (seed cotton and boll shell). Compared with OPT, OPT-K and OPT$\mathrm{W}-\mathrm{K}$ treatments showed sharp decreases in $\mathrm{K}$ concentrations in cotton leaves and reproductive organs. 
Table 2. $\mathrm{K}$ concentrations in different tissues of cotton plant ( $\left.\mathrm{mg} \mathrm{g}^{-1}\right)$.

\begin{tabular}{|c|c|c|c|c|c|c|c|}
\hline Genotypes & Treatments & Root & Stem & Leaf & $\begin{array}{l}\text { Seed } \\
\text { cotton }\end{array}$ & $\begin{array}{l}\text { Boll } \\
\text { shell }\end{array}$ & Total \\
\hline \multirow[t]{4}{*}{ HEG } & OPT & $5.91 \mathrm{a}$ & $5.21 \mathrm{a}$ & $9.79 \mathrm{a}$ & $14.78 \mathrm{a}$ & $14.90 \mathrm{a}$ & $10.28 \mathrm{a}$ \\
\hline & OPT-W & $6.70 \mathrm{a}$ & $4.44 \mathrm{a}$ & $6.74 \mathrm{~b}$ & $16.74 \mathrm{a}$ & $12.81 \mathrm{ab}$ & $9.48 \mathrm{a}$ \\
\hline & OPT-K & $2.74 \mathrm{~b}$ & $1.80 \mathrm{~b}$ & $1.11 \mathrm{c}$ & $15.78 \mathrm{a}$ & $9.63 \mathrm{~b}$ & $6.21 \mathrm{~b}$ \\
\hline & OPT-W-K & $3.51 \mathrm{~b}$ & $2.73 \mathrm{~b}$ & $0.95 \mathrm{c}$ & $14.75 \mathrm{a}$ & $11.03 \mathrm{ab}$ & $6.20 \mathrm{~b}$ \\
\hline \multirow[t]{4}{*}{ LEG } & OPT & $5.99 \mathrm{a}$ & $6.30 \mathrm{a}$ & $9.07 \mathrm{a}$ & $11.17 \mathrm{~b}$ & $22.73 \mathrm{a}$ & $10.24 \mathrm{a}$ \\
\hline & OPT-W & $6.55 \mathrm{a}$ & $5.68 \mathrm{a}$ & $8.90 \mathrm{a}$ & $15.56 \mathrm{a}$ & $20.68 \mathrm{a}$ & $10.52 \mathrm{a}$ \\
\hline & OPT-K & $2.89 \mathrm{~b}$ & $2.64 \mathrm{~b}$ & $1.26 \mathrm{~b}$ & $14.86 \mathrm{ab}$ & $14.42 \mathrm{~b}$ & $6.69 \mathrm{~b}$ \\
\hline & OPT-W-K & $3.45 \mathrm{~b}$ & $3.20 \mathrm{~b}$ & $1.28 \mathrm{~b}$ & $12.81 \mathrm{ab}$ & $15.60 \mathrm{~b}$ & $6.29 \mathrm{~b}$ \\
\hline \multicolumn{8}{|c|}{ Source of variation (Two-way ANOVA) } \\
\hline \multicolumn{2}{|c|}{ Genotypes(G) } & NS & ** & NS & ** & ** & NS \\
\hline \multicolumn{2}{|c|}{ Treatments(T) } & $* *$ & $* *$ & ** & ** & ** & $* *$ \\
\hline \multicolumn{2}{|l|}{ G\&T } & NS & NS & NS & NS & NS & NS \\
\hline
\end{tabular}

$\mathrm{OPT}=$ Optimum water and $\mathrm{K}, \mathrm{OPT}-\mathrm{W}=$ Water stress, $\mathrm{OPT}-\mathrm{K}=\mathrm{K}$ stress, OPT-W-K= water and $\mathrm{K}$ stresses. $\mathrm{HEG}=$ high efficiency genotype and $\mathrm{LEG}=$ low efficiency genotype. ${ }^{* *}$ means significant difference at $1 \%$ level $(P<0.01),{ }^{*}$ means significant difference at $5 \%$ level $(P<0.05)$ and NS means not significant. Different letters indicated significant difference between treatments by Tukey test $(P<0.05)$, the same below.

Yield, $\mathrm{K}$ accumulation in reproductive organs (RKA) and total K (TK) of HEG were higher than that of LEG (Table 3). The yield, RKA and TK of chosen cotton genotypes followed the order OPT $>$ OPT-K $>$ OPT-W $>$ OPT-W-K, indicating that low soil water content could severely inhibit cotton growth, biomass and $\mathrm{K}$ accumulation.
In OPT-W-K treatment, the TK and RKA were lower than those in OPT-K treatment. Therefore, it is interesting to mention that soil water content might affect the $\mathrm{K}$ fertilizer efficiency through reducing $\mathrm{K}$ translocation in plant tissues and affecting the mobility of soil indigenous $\mathrm{K}$ to plant roots. 
Table 3. Effects of different water and $\mathrm{K}$ treatments on yield, biomass and $\mathrm{K}$ accumulation in two cotton genotypes.

\begin{tabular}{|c|c|c|c|c|c|c|}
\hline Genotypes & Treatments & $\begin{array}{l}\text { Yield } \\
\text { (g.plant } \\
\text { 1) }\end{array}$ & $\begin{array}{l}\text { DMW } \\
\text { (g.plant } \\
\text { 1) }\end{array}$ & $\begin{array}{c}\text { TK } \\
\text { (mg.plant } \\
\text { 1) }\end{array}$ & $\begin{array}{c}\text { RKA } \\
\text { (mg.plant } \\
\text { 1) }\end{array}$ & RKA/TK \\
\hline \multirow{4}{*}{ HEG } & OPT & $12.5 \mathrm{a}$ & $48.8 \mathrm{a}$ & $500.1 \mathrm{a}$ & $288.9 \mathrm{a}$ & $57.8 b$ \\
\hline & OPT-W & $6.1 \mathrm{c}$ & $26.1 \mathrm{~b}$ & $246.7 \mathrm{c}$ & $154.6 \mathrm{c}$ & $62.7 \mathrm{~b}$ \\
\hline & OPT-K & $10.2 b$ & $45.7 \mathrm{a}$ & $283.8 b$ & $235.1 b$ & $82.9 \mathrm{a}$ \\
\hline & OPT-W-K & $5.1 \mathrm{c}$ & $24.4 b$ & $150.6 \mathrm{~d}$ & $118.6 \mathrm{~d}$ & $78.8 \mathrm{a}$ \\
\hline \multirow{4}{*}{ LEG } & OPT & $10.8 \mathrm{a}$ & $46.9 \mathrm{a}$ & $481.4 \mathrm{a}$ & $255.2 \mathrm{a}$ & $53.0 \mathrm{~b}$ \\
\hline & OPT-W & $5.3 \mathrm{c}$ & $24.9 \mathrm{c}$ & $253.0 \mathrm{~b}$ & $140.3 \mathrm{c}$ & $55.5 b$ \\
\hline & OPT-K & $8.1 \mathrm{~b}$ & $39.0 \mathrm{~b}$ & $256.8 b$ & $200.3 b$ & $78.0 \mathrm{a}$ \\
\hline & OPT-W-K & $4.0 \mathrm{~d}$ & $22.6 \mathrm{c}$ & $142.4 \mathrm{c}$ & $106.7 \mathrm{c}$ & $75.0 \mathrm{a}$ \\
\hline \multicolumn{7}{|c|}{ Source of variation (Two-way ANOVA) } \\
\hline \multicolumn{2}{|c|}{ Genotypes $(G)$} & $* *$ & $* *$ & NS & $* *$ & $* *$ \\
\hline \multicolumn{2}{|c|}{ Treatments(T) } & $* *$ & $* *$ & $* *$ & $* *$ & $* *$ \\
\hline \multicolumn{2}{|c|}{ G\&T } & $*$ & NS & NS & NS & NS \\
\hline
\end{tabular}

$\mathrm{TK}=$ total potassium and $\mathrm{RKA}=\mathrm{K}$ accumulation in reproductive organ.

\section{3. $K$ and biomass distribution}

Figure 2 showed that the $\mathrm{K}$ accumulation in reproductive organs (seed cotton and boll shell) accounted for $53.0 \% \sim 82.9 \%$ of TK in different treatments. The RKA/TK ratio in HEG was $4.8 \%, 7.2 \%, 4.9 \%$ and $3.8 \%$ higher than those in LEG for OPT, OPT-W, OPT-K and OPT$\mathrm{W}-\mathrm{K}$ treatments, respectively (Table 3 ). The largest difference between the two genotypes was found in OPT-W treatment. Moreover, the RKA/TK ratio revealed that HEG had stronger transportation ability than LEG and could transport greater proportion of $\mathrm{K}$ to reproductive organs under stresses conditions, especially under low $\mathrm{K}$ content. The ratio between reproductive organs biomass and vegetative organs $(\mathrm{R} / \mathrm{V})$ and rate of fallen leaves, buds and bolls (RF) could also reflect the distribution tendencies of the absorbed $\mathrm{K}$ among bolls and other plant organs (Figure 3 ). The value of RF showed that there was a large loss of biomass in the shedding buds and bolls of the two cotton genotypes under stress conditions. The RF of LEG was higher than that of HEG in all treatments, but the differences between the two cotton genotypes were not significant, especially in the OPT-W treatment. In addition, the differences between the two cotton genotypes in RF and R/V increased with the stress rising, especially under low $\mathrm{K}$ stress conditions. However, there was no significant difference between the two cotton genotypes under low water content conditions. The HEG had higher $\mathrm{R} / \mathrm{V}$ and lower RF as compared to 
LEG in different treatments, indicating that HEG had higher resistance to stress conditions. The R/V data of HEG increased in OPT-W and OPT-K treatments, but the $\mathrm{R} / \mathrm{V}$ data of $\mathrm{LEG}$ decreased. The results indicated that HEG had higher physiological superiority under low $\mathrm{K}$ stress condition as compared to under drought conditions.
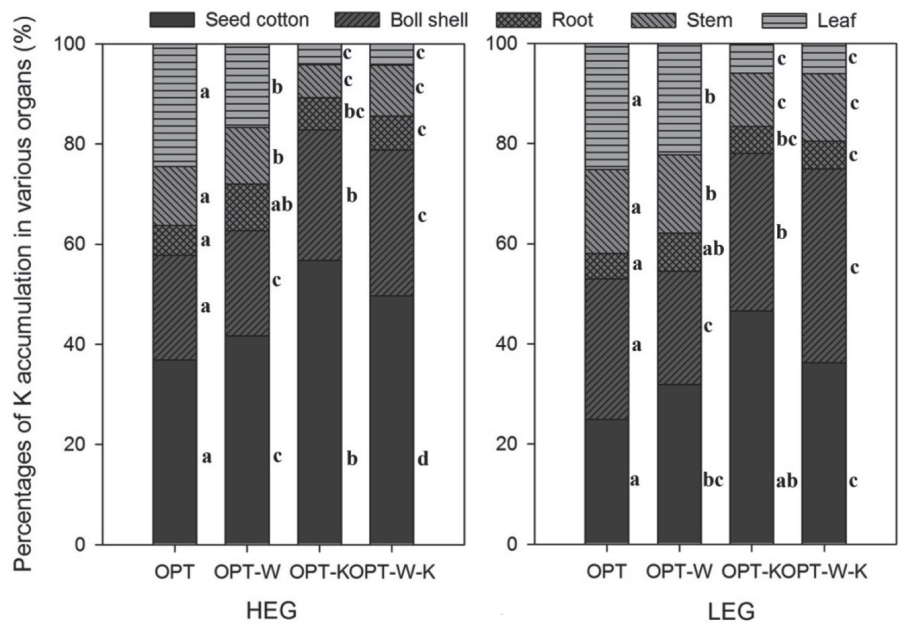

Figure 2. Effects of different water and $\mathrm{K}$ treatments on $\mathrm{K}$ accumulation percentages in various organs of two cotton genotypes. Different letters indicated the significant differences between the treatments by Tukey's multiple range test $(P<0.05)$. OPT $=$ Optimum water and $\mathrm{K}, \mathrm{OPT}-\mathrm{W}=$ Water stress, $\mathrm{OPT}-\mathrm{K}=$ $\mathrm{K}$ stress, OPT-W-K= water and $\mathrm{K}$ stresses.

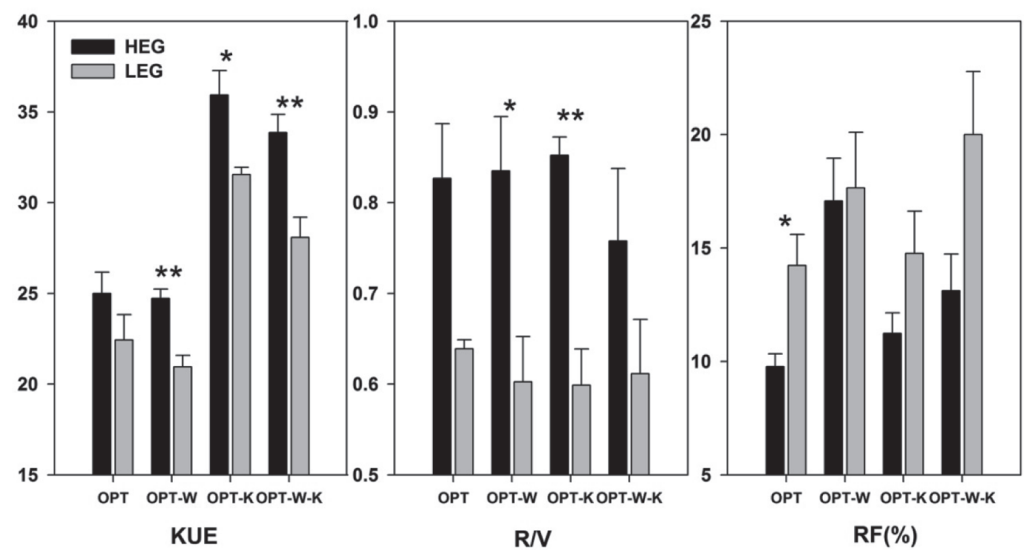

Figure 3. Effects of different water and $\mathrm{K}$ treatments on KUE, RF and R/V of two cotton genotypes. Bars represent means of 5 replications \pm standard errors $(n=4)$. Independent $T$ test was performed to check genotypic difference at different treatments separately $(* * P<0.01 ; * P<0.05)$. KUE $=$ Yield/TK, $\mathrm{RF}=$ biomass of exfoliation per plant/total biomass per plant, $\mathrm{R} / \mathrm{V}=$ biomass of reproductive organs per plant/biomass of vegetative organs per plant. 


\subsection{K utilization efficiency}

The $\mathrm{K}$ use efficiency (KUE) values of HEG were 25.0, 24.9, 36.1 and 33.8 and those of LEG were 22.6, 20.9, 31.3 and 28.3 for OPT, OPT-W, OPT-K and OPT-W-K treatments, respectively (Figure 3). The highest KUE values of cotton genotypes were observed in OPT-K treatment, and the KUE decreased with increase of $\mathrm{K}$ application rates. Also, cotton genotypes showed significant variations in KUE for all the studied treatments.

\section{Discussion}

indicated that HEG had higher yield, DMW, TK and KUE than LEG in all treatments and showed stronger resistance to stress conditions, especially under low $\mathrm{K}$ conditions. It was not very clear to confirm which factors (higher uptake or utilization ability) could be responsible for significant differences in KUE between the two cotton genotypes. The data in Table 2 and Figure 2 revealed that the soil water contents and $\mathrm{K}$ application rates had effects on $\mathrm{K}$ concentrations and its distribution among cotton tissues. Figure 2 showed obviously that the highest $\mathrm{K}$ concentrations were found in cotton leaves and reproductive organs. The $\mathrm{K}$ concentrations of cotton leaves decreased sharply in the absent of $\mathrm{K}$ vis-à-vis under optimum conditions, but there were no significant changes recorded in the $\mathrm{K}$ concentrations of reproductive organs. These results indicated that when $\mathrm{K}$ was sufficient, cotton roots could transport $\mathrm{K}$ into leaves to promote the production of chlorophyll and enhance the photosynthesis process, in order to maintain leaf function and the plant growth.
However, when $\mathrm{K}$ was deficient, cotton did not absorb enough amounts of $\mathrm{K}$ to transport to reproductive organs, which caused limited growth for seeds and bolls.

Khas an important role to improve plant resistance to extreme drought stress (Raza et al. 2014). Potassium ions $\left(\mathrm{K}^{+}\right)$can affect water transport in whole plant, maintain cell pressure, and regulate opening and closing of stomata (Valadabadi and Farahani 2010; Raza et al. 2013). Our research indicated that the concentrations of $\mathrm{K}^{+}$in various cotton organs under the OPT-W treatment were higher than that under the OPT-W-K treatment (Table 2). Wei et al. (2013) found that external $\mathrm{K}$ may increase plant drought tolerance of wheat by enhancing internal $\mathrm{K}^{+}$concentration under drought stress, which was consistent with our result. Soil moisture can also influence the uptake rate of $\mathrm{K}$ via affecting its mobility from the soil to the root surface. Our results are in agreement with Kuchenbuch et al. (1986), who confirmed that soil moisture is one of the major factors controlling the availability of $\mathrm{K}$. The absorption of $\mathrm{K}$ by plants from soil was mainly depended on mass flow and diffusion ways, which were highly influenced by the presence of enough water (Oliveira et al. 2010). The lack of soil moisture can reduce soil $\mathrm{K}$ availability and then its uptake and transportation by plants and also restrict the photosynthetic cycle. Soil water and $\mathrm{K}$ contents not only affected the photosynthetic efficiency, but also regulated the photosynthates distribution (Waraich et al. 2011).

In conclusion, the yield, KUE, $\mathrm{K}$ accumulation and $\mathrm{K}$ distribution of cotton organs are some of the major indicators to evaluate $\mathrm{K}$ utilization capacity of the plant. In our study, the growth of the chosen cotton genotypes can be inhibited by 
water and $\mathrm{K}$ stresses. HEG was more resistance to drought and $\mathrm{K}$ stresses than LEG in this experiment. Better root growth increased the nutrient uptake ability of root and led to good nutrient supply to plants. The results concluded that HEG cotton genotype could retain more normal plant growth and yield than LEG under soil moisture and $\mathrm{K}$ stresses.

\section{Acknowledgments}

This research work was financial supported by the National Natural Science Foundation of China (41171243) and the China Program of International Plant Nutrition Institute (IPNIHB-34). We thank Dr. Jiang Cun-cang at Huazhong Agricultural University, and the Cotton Research Institute of Chinese Academy of Agricultural Sciences for their support.

\section{References}

Adeli, A., Varco, J.J. 2002. Potassium management effects on cotton yield, nutrition, and soil potassium level. J. Plant Nutr. 2, 2229-2242.

Alian, A., Altman, A., Heuer, B. 2000. Genotypic difference in salinity and water stress tolerance of fresh market tomato cultivars. Plant Sci. 152, 59-65.

Clement-Bailey, J., Gwathmey, C.O. 2007. Potassium effects on partitioning, yield, and earliness of contrasting cotton cultivars. Agron. J. 99, 1130-1136.

Damon, P.M., Ma, Q.F., Rengel, Z. 2011. Wheat genotypes differ in potassium accumulation and osmotic adjustment under drought stress. Crop Pasture Sci. 62, 550-555.
Doussan, C., Pagès, L., Pierret A. 2003. Soil exploration and resource acquisition by plant roots: an architectural and modelling point of view. Agron. Sus. Dev. 23, 419-432.

George, M.S., Lu, G.Q., Zhou, W.J. 2002. Genotypic variation for potassium uptake and utilization efficiency in sweet potato (Ipomoea batatas L.). Field Crop. Res. 77, 7-15.

Gormus, O. 2002. Effects of rate and time of potassium application on cotton yield and quality in Turkey. J. Agron. Crop Sci. 188, 382-388.

Gwathmey, C.O., Main, C.L., Yin, X. 2009. Potassium uptake and partitioning relative to dry matter accumulation in cotton cultivars differing in maturity. Agron. J. 101, 14791488.

Hattori, D., Kenzo, T., Yamauchi, N., Irino, K.O., Kendawang, J.J., Ninomiya, I., Sakurai, K. 2013. Effects of environmental factors on growth and mortality of Parashorea macrophylla (Dipterocarpaceae) planted on slopes and valleys in a degraded tropical secondary forest in Sarawak, Malaysia. Soil Sci. Plant Nutr. 59, 218-228.

Jiang, C.C., Xia, Y., Chen, F., Lu, J.W., Wang, Y.H. 2011. Plant Growth, Yield Components, Economic Responses, and Soil Indigenous K Uptake of Two Cotton Genotypes with Different K-Efficiencies. Agri. Sci. China. 10, 705-713.

Kuchenbuch, R., Claassen, N., Jungk, A. 1986. Potassium availability in relation to soil moisture: 2. Calculations by means of a mathematical simulation model. Plant Soil. 95, 233-243. 
Makhdum, M.I., Pervez, H., Ashraf, M. 2007. Dry matter accumulation and partitioning in cotton (Gossypium hirsutum L.) as influenced by potassium fertilization. Biol. Fert. Soil. 43, 295-301.

Mallarino, A.P., Wittry, D.J., Barbagelata, P.A. 2003. New soil test interpretation classes for potassium. Better Crops. 87, 12-14.

Moritsuka, N., Yanai, J., Kosaki, T. 2000. Effect of plant growth on the distribution and forms of soil nutrients in the rhizosphere. Soil Sci. Plant Nutr. 46, 439-447.

$\mathrm{Mu}$, X.M. 1999. The coupling effect of water and nitrogen and concerted management. China Forestry Press, Beijing, pp.18-19, 38.

Mullins, G.L., Burmester C.H., Reeves, D.W. 1997. Cotton response to in-row subsoiling and potassium fertilizer placement in Alabama. Soil Till. Res. 40, 145-154.

Oliveira, E.M.M., Ruiz, H.A., Alvarez, V.H., Ferreira, P.A., Costa F.O., Almeida, I.C.C. 2010. Nutrient supply by mass flow and diffusion to maize plants in response to soil aggregate size and water potential. Rev. Brasil. de Ciên. do Solo. 34, 317-327.

Pettigrew, W.T. 2008. Potassium influences on yield and quality production for maize, wheat, soybean and cotton. Physiol. Plant. 133, 670-681.

Quezada, C., Fischer, S., Campos, J., Ardiles, D. 2011. Water management efficiency for carrot under drip irrigation in a haploxerand soil. J. Soil Sci. Plant Nutr. 11, 16-28.

Raza, M.A.S., Saleem, M.F., Shah, G.M., Jamil, M., Khan, I.H. 2013. Potassium applied under drought improves physiological and nutrient uptake performances of wheat (Triticum Aestivun L.). J. Soil Sci. Plant Nutr. 13, 175-185.
Raza, M.A.S., Saleem, M.F., Shah, G.M., Khan, I.H., Raza, A. 2014. Exogenous application of glycinebetaine and potassium for improving water relations and grain yield of wheat under drought. J. Soil Sci. Plant Nutr. 14, 348-364.

Reddy, K.R., Zhao, D.L. 2005. Interactive effects of elevated $\mathrm{CO}_{2}$ and potassium deficiency on photosynthesis, growth, and biomass partitioning of cotton. Field Crop. Res. 94, 201-213.

Saparov, A., Eleshev, R., Suleimenov, B., Peskovki, G., Shcherbakov, A. 2013. Effect of Potassium Chloride Application for Rice, Cotton and Potato in the Irrigated Zone of Kazakhstan. Better Crops with Plant Food. 97, 23-25.

Siddique, M, Hamid, A., Islam, M. 2000. Drought stress effects on water relations of wheat. Bot. Bull. Acad. Sin. 41, 35-39.

Steingrobe, B., Claassen, N. 2000. Potassium dynamics in the rhizosphere and $\mathrm{K}$ efficiency of crops. J. Plant Nutr. Soil Sci. 163, 101106.

Tao, Y., Wang, L., Wang, X., Xia, Y., Wan, K.Y., Chen, F. 2012. Adaptive Phenotypic Differences to Low Potassium Soil of Two Cotton Genotypes with Various Potassium Use Efficiencies. Commun. Soil Sci. Plant Anal. 43, 1984-1993.

Valadabadi, S., Farahani, H.A. 2010. Studying the interactive effect of potassium application and individual field crops on root penetration under drought condition. J. Agri. Biotechnol. Sus. Dev. 2,82-86.

Wang, L., Chen F. 2012. Genotypic variation of potassium uptake and use efficiency in cotton (Gossypium hirsutum). J. Plant Nutr. Soil Sci. 175, 303-308. 
Wang, S.Q. 2002. Test on applying potash fertilizer measures of cotton in damp farm soil. Hubei Agriculture Sciences. 2, 44-46. In Chinese.

Wang, X., Xia, Y., Wang, L., Chen F. 2012. Research on the response of different potassium efficiency cotton genotypes to water and low potassium stress, Chinese Agricultural Science Bulletin. 28, 60-65. In Chinese.

Waraich, E.A., Ahmad, R., Ashraf, M.Y., Saifullah, Ahmad, M. 2011. Improving agricultural water use efficiency by nutrient management in crop plants. Acta Agriculturae Scandinavica, Section B-Soil \& Plant Science, 61, 291-304.

Wei, J.G., Li, C.H., Li, Y., Jiang, G.M., Cheng, G.L., Zheng, Y.H. 2013. Effects of external potassium (k) supply on drought tolerances of two contrasting winter wheat cultivars. Plos One. 8, e69737.
White, P.J. 2013. Improving potassium acquisition and utilisation by crop plants. J. Plant Nutr. Soil Sci. 176, 305-316.

Xia, Y., Jiang, C.C., Chen, F., Lu, J.W., Wang, Y.H. 2011. Differences in growth and potassium-use efficiency of two cotton genotypes. Commun. Soil Sci. Plant Anal. 42, 132-143.

Xia, Y., Jiang, C.C., Wang, X., Chen, F. 2013. Studies on potassium uptake and use efficiency of different cotton (Gossypium hirsutum L.) genotypes by grafting. J. Food Agric. Environ. 11, 472-476.

Yang, F.Q., Wang, G.W., Zhang, Z.Y., Eneji, A.E., Duan, L.S., Li, Z.H., Tian, X.L. 2010. Genotypic variations in potassium uptake and utilization in cotton. J. Plant Nutr. 34, 83-97. 